\title{
DOE/RW/0013/f-302-96 \\ High-level Radioactive Waste Management in the United States \\ Background and Status: 1996
}

J. Russell Dyer ${ }^{1}$ and M. D. Voegele ${ }^{2}$

\section{Introduction}

The United States high-level radioactive waste disposal program is investigating a site at Yucca Mountain, Nevada, to determine whether or not it is a suitable location for the development of a deep mined geologic repository. At this time, the United States program is investigating a single site, although in the past, the program involved successive screening and comparison of alternate locations. The United States civilian reactor programs do not reprocess spent fuel; the high-level waste repository will be designed for the emplacement of spent fuel and a limited amount of vitrified high-level wastes from previous reprocessing in the United States. The legislation enabling the United States program [1] also contains provisions for a Monitored Retrievable Storage facility, which could provide temporary storage of spent fuel accepted for disposal, and improve the flexibility of the repository development schedule.

Yucca Mountain is a mountainous ridge located in the southwestern United States (Figure 1) in the southern Great Basin, the largest subprovince of the Basin and Range physiographic province of the United States. The Basin and Range province is that area of southwestern North America that is characterized by more or less regularly spaced subparallel mountain ranges and intervening alluvial basins formed by extensional faulting. The regional climate of the southern Great Basin is typically hot and semi-arid. Generally, the geology of the province can be described as a late Precambrian and Paleozoic continental margin assemblage that has been complexly deformed by late Paleozoic and Mesozoic orogenies. Western portions of the province are broadly overlain by Cenozoic volcanic rocks; the distinctive physiography is largely a product of the most recent phase of extensional deformation. The alluvial basins are characterized by low rainfall, high evapotranspiration, ephemeral streams and closed hydrologic systems, evidenced by the absence of drainage external to the basins [2]. Characteristics such as these were important waste isolation considerations in the selection of Yucca Mountain for site characterization.

The repository design concept is a mined excavation at a depth of approximately 300 meters below the crest of Yucca Mountain and at a distance of approximately 300 meters above the regional groundwater table. The site is in silicic volcanic rocks, comprising alternating layers of welded and non-welded volcanic tuffs. The non-welded tuffs underlying the proposed repository horizon contain layers that are extensively zeolitized. The strategy for waste

${ }^{1}$ Deputy Project Manager, Yucca Mountain Site Characterization Office, United States Department of Energy; '2Deputy Manager Technical Programs, Civilian Radioactive Waste Management Systems Management and Operating Contractor 


\section{DISCLAIMER}

This report was prepared as an account of work sponsored by an agency of the United States Government. Neither the United States Government nor any agency thereof, nor any of their employees, makes any warranty, express or implied, or assumes any legal liability or responsibility for the aceuracy, completeness, or usefulness of any information, apparatus, product, or procene disclosed, or represents that its use would not infringe privately owned righx. Reference herein to any specific commercial produch, process, or service by trade name, trademarie, inanufacturet, or otherwise does not necessarily constitute or imply its eadorsement, recommendation. or favoring by the United States Government or any ageocy thereof. The views and opinions of authors expressed herein do not neccunrily state or rellect those of the United States Government or any agency thereof. 


\section{DISCLAIMER}

Portions of this document may be illegible in electronic image products. Images are produced from the best available original document. 


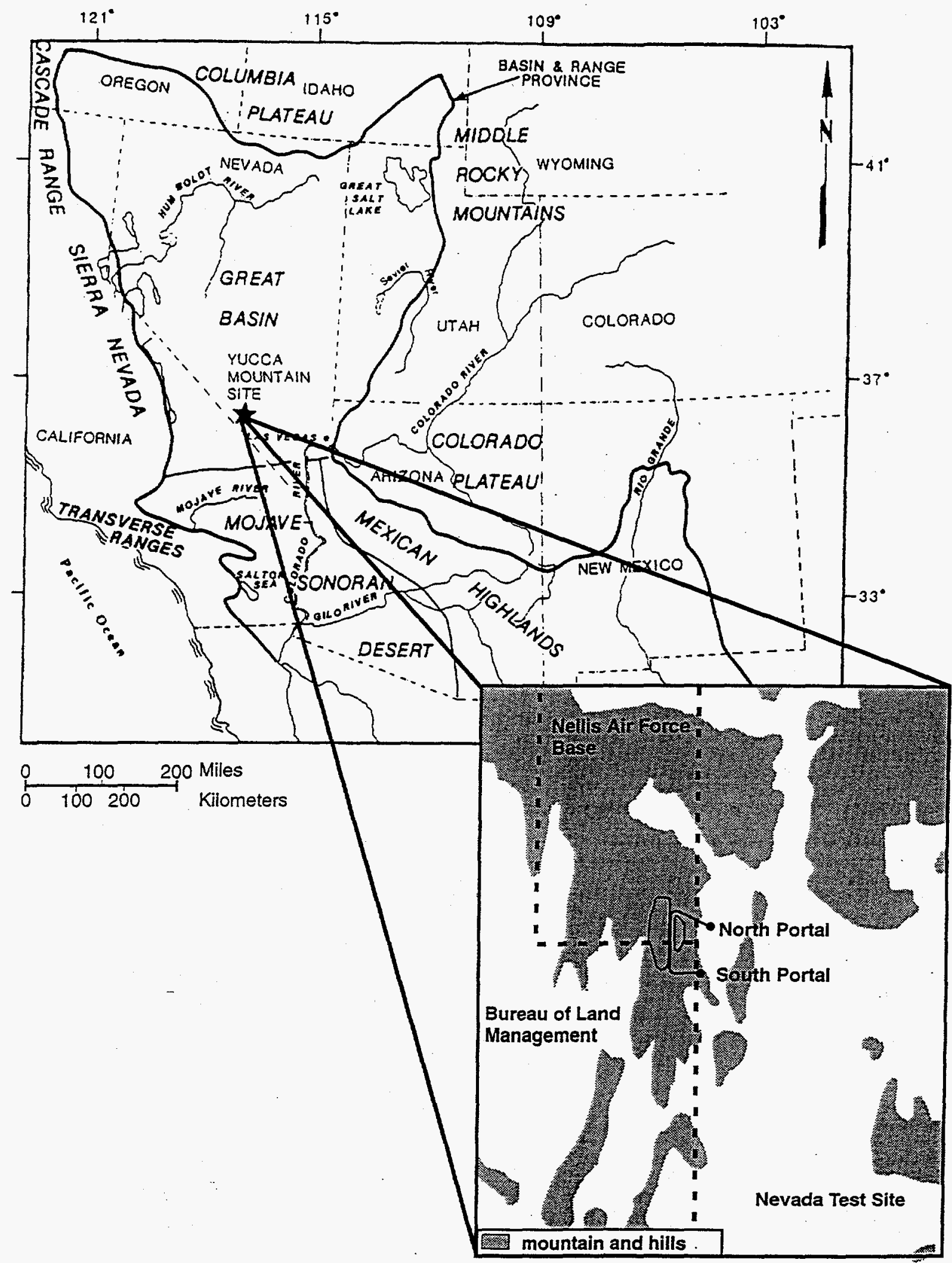

Figure 1. Location map for Great Basin Physiographic Province and Yucca Mountain Site. 
isolation relies on both engineered and natural barriers to provide defense in depth. The strategy for long term waste isolation places primary reliance on, and takes advantage of, the natural barriers, which include the aridity of the site, the unsaturated character of the host rock, and the deep regional water table. All indications are that these geologic conditions have been both spatially and temporally stable for many millions of years.

The United States high-level waste disposal program is managed separately from activities related to the management of transuranic waste from national security activities or commerciallygenerated low-level wastes. The transuranic waste program in the United States is also pursuing development of a mined geologic repository for disposal [3]. The Waste Isolation Pilot Plant, located near Carlsbad, New Mexico, is constructed in a salt formation.

\section{Legislative Background}

The high-level waste disposal program in the United States evolved through several different approaches between 1955 and 1982. In 1955, the National Academy of Sciences was asked to recommend a strategy for the disposal of liquid chemically hazardous radioactive wastes resulting from the reprocessing of spent nuclear fuel. The National Academy of Sciences recommended disposal in salt formations, to take advantage of the evident geologic stability and isolation from water. Subsequently, the United States program recognized the advantages of other rock characteristics, and began a program of national screening in the late 1970s. In 1982, the United States Congress passed the Nuclear Waste Policy Act (the Act) [4], setting forth an integrated plan for the disposal of commercially-generated spent fuel and high-level wastes from military reprocessing. The Act established responsibilities, schedules, and a funding mechanism whereby the users of nuclear power would pay for the disposal of the generated wastes. A portion of the wastes generated through various United States defense programs are included in the provisions of this law.

Under the Act, the United States Department of Energy was assigned responsibility for management of the civilian high-level waste program, the United States Nuclear Regulatory Commission was assigned responsibility for approving or disapproving a license to construct a repository and amendments to operate and close it, and the United States Environmental Protection Agency was assigned responsibility for promulgation of generally applicable standards for protection of the general environment from offsite releases from radioactive material in repositories. The United States Environmental Protection Agency promulgated its standard [5] in 1985. This standard was not explicitly health based; the postclosure behavior of a repository licensed under this regulation would be judged against total cumulative releases at the end of a 10,000 year period. In 1987 , a court challenge, based to some degree on inconsistency with other United States Environmental Protection Agency regulations, led to a remand of the standard. The United States Nuclear Regulatory Commission had already promulgated its procedural and technical requirements [6] by 1983 . Those requirements, which implement rather than duplicate the United States Environmental Protection Agency release standards, address the concepts of multiple barriers and defense in depth, placing specific requirements for postclosure performance of the repository on components of both the engineered and natural subsystems. 
Following completion of site characterization, the United States Department of Energy will submit initial documentation for a licensing hearing to authorize construction of the repository. Authorization of construction will be based in part on an understanding of the long term performance of the proposed repository. The United States Nuclear Regulatory Commission requirements embody a phased approach to construction and emplacement of high-level wastes in a repository. After sufficient construction to affirm that site conditions and underground excavation response are within the limits specified in the license to construct, the applicant submits documentation for a hearing for a license to receive and possess wastes. Amendment of the license to allow the repository to receive and possess wastes marks the first point in time that high-level wastes can be emplaced for disposal in the repository. With the approval of the United States Nuclear Regulatory Commission, up to ten metric tons of spent fuel could be emplaced for testing purposes during site characterization. Other than this limited amount of waste allowed for use by the Nuclear Waste Policy Act for purposes of site characterization (the provision was not invoked by the United States Department of Energy for Yucca Mountain), radioactive wastes are not permitted to be emplaced until this license is received. After operation of the repository and a defined period of monitoring, an application is submitted for a license amendment to decommission and then permanently close the repository.

The intention of the Program created by the 1982 Nuclear Waste Policy Act [4] was to characterize multiple sites and recommend sites for development as repositories. The Act envisioned the need for two repositories in the commercial waste program; with geographical diversity and consideration. Accordingly, it directed the United States Department of Energy to undertake two repository characterization programs. The Act specified that the United States Department of Energy develop guidelines and prepare Environmental Assessments to be used as the basis for selecting each set of three sites to be characterized. The Act also explicitly required the preparation, and submittal for review by the United States Nuclear Regulatory Commission, of a Site Characterization Plan. It was the intent of the Act that following completion of the characterization of three candidate sites for each repository, Environmental Impact Statements would be prepared and serve as the basis for the recommendations of the sites for which the United States Department of Energy would apply for a license to construct a repository. In 1987, the United States Congress amended the Act. The Nuclear Waste Policy Amendments Act [1] selected Yucca Mountain, Nevada, as the single site to be characterized. The amendment also directed the United States Department of Energy to cease work on the second repository program.

The United States Congress recently passed a comprehensive Energy Policy Act [7] that contained provisions that probably will affect the regulations governing a repository at Yucca Mountain. That legislation required the United States Environmental Protection Agency, based upon, and consistent with the findings and recommendation of a study to be undertaken by the United States National Academy of Sciences, to promulgate public health and safety standards for protection of the public from releases from radioactive materials stored or disposed of in the repository at the Yucca Mountain site. These standards are to prescribe the maximum annual effective dose equivalent to individual members of the public. The issue of a dose-based standard for the United States high-level waste program dates back to the United States 
Environmental Protection Agency's own Science Advisory Board and the National Academy of Sciences [8] noting that such a standard would be appropriate for the United States Program.

The National Academy of Sciences study [9] provided recommendations as to whether a health based standard is reasonable, whether it is reasonable to assume that a system of postclosure oversight, based on active controls, will prevent a risk of breaching the repository, and whether it is possible to make scientifically sound predictions of the probability of human intrusion over 10,000 years. The United States Environmental Protection Agency currently is in the process of developing a new compliance standard for the Yucca Mountain site that addresses these recommendations.

\section{Yucca Mountain Site Waste Isolation Strategy}

The strategy for waste isolation for the Yucca Mountain site consists of reliance on a number of barriers, both natural and engineered, that either are attributes of the site or are engineered in a manner to complement the site attributes [2]. As water is the medium that can dissolve and transport solid wastes, the strategy takes advantage of the paucity of water at the site.

Yucca Mountain is a remote mountainous ridge located in the arid southwestern United States (Figure 2), where rainfall averages approximately 15 centimeters per year. The water table in the vicinity of the Yucca Mountain site is deep, approximately 700 meters below the crest. Placing a repository at a depth of approximately 200 to 300 meters below the surface would leave a distance of several hundred meters between the repository and the water table. The repository would thus be in unsaturated rocks, with water held in place by capillary forces. The stratigraphy at Yucca Mountain consists of alternating layers of welded and non-welded volcanic tuffs. The welded tuff matrix is relatively impermeable; however, the rocks are fractured and will transmit water provided there is a sufficient source. The non-welded tuffs are porous and permeable; however, they tend to form capillary barriers at contacts with the welded tuff units and transmit significant quantities of water only when fully saturated. The repository would be located in a thick welded layer, overlain by a non-welded layer with a welded caprock (Figure 3). Conceptually, this combination should be effective in limiting the amount of water that could eventually reach the emplaced wastes. The rock beneath the repository area includes layers that are conspicuously zeolitized, providing the potential for retarding the transport of some radionuclides.

It is intended that the engineered components of the repository complement the natural attributes of the site. The subsurface layout of the repository, as shown in Figure 4 and Figure 5, would comprise two inclined access ramps, two vertical ventilation shafts, and essentially flat-lying main and waste emplacement drifts.

The waste container is expected to function as the principal barrier to the release of radionuclides from the engineered barrier system. The barrier will be designed to provide substantially complete containment of the wastes for at least the time that heat and radiation 


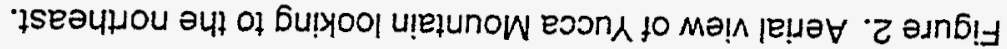

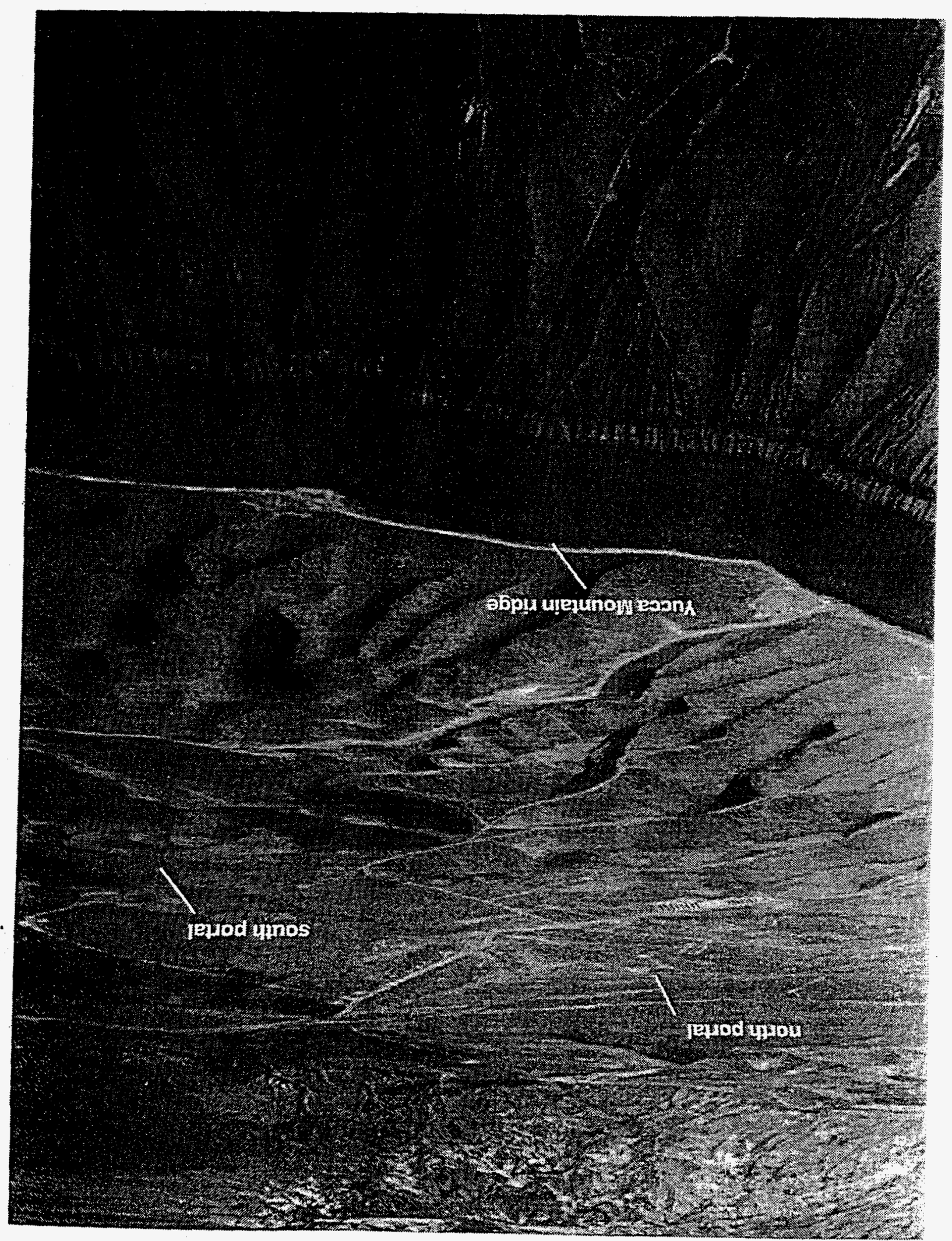




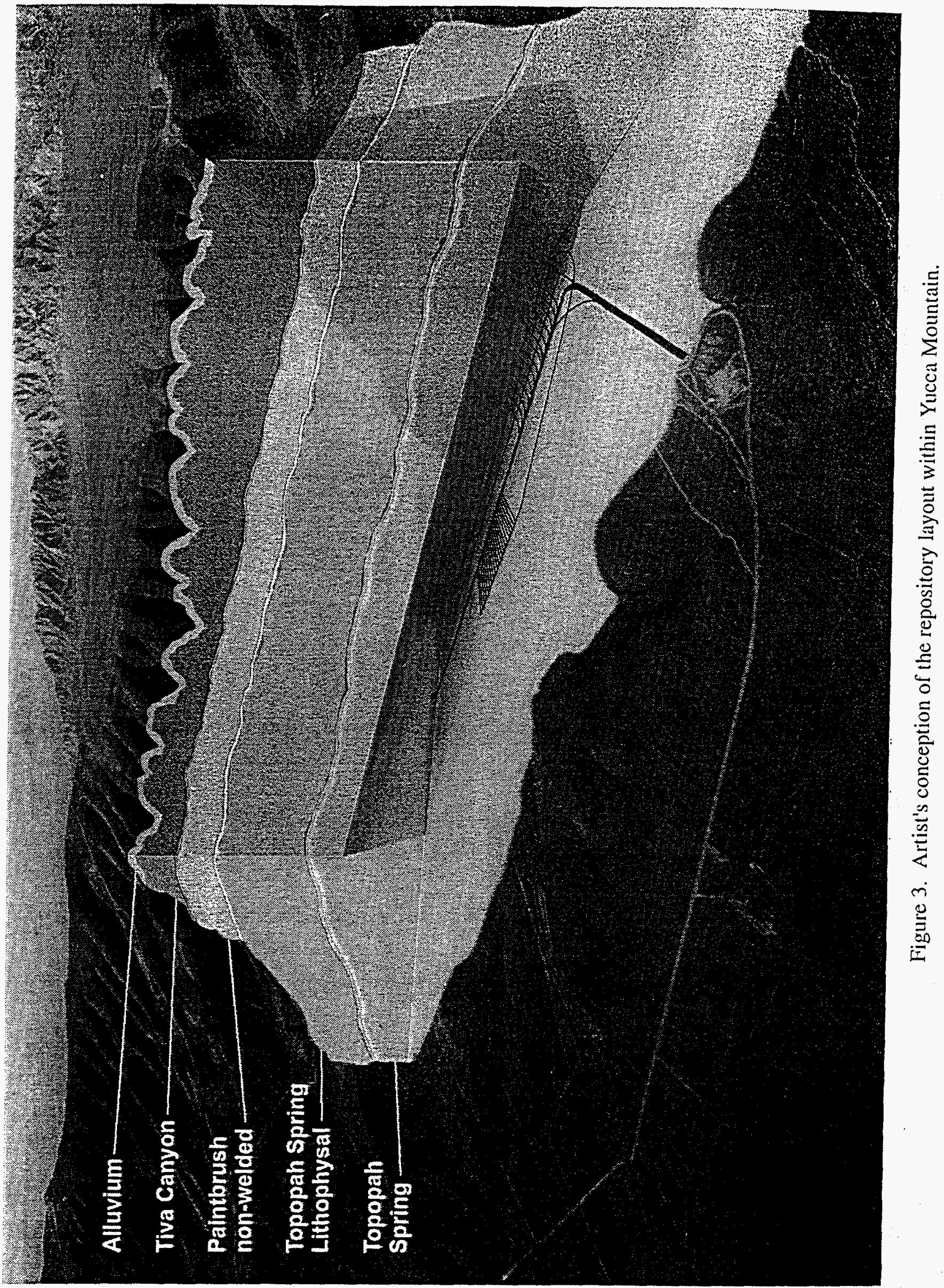




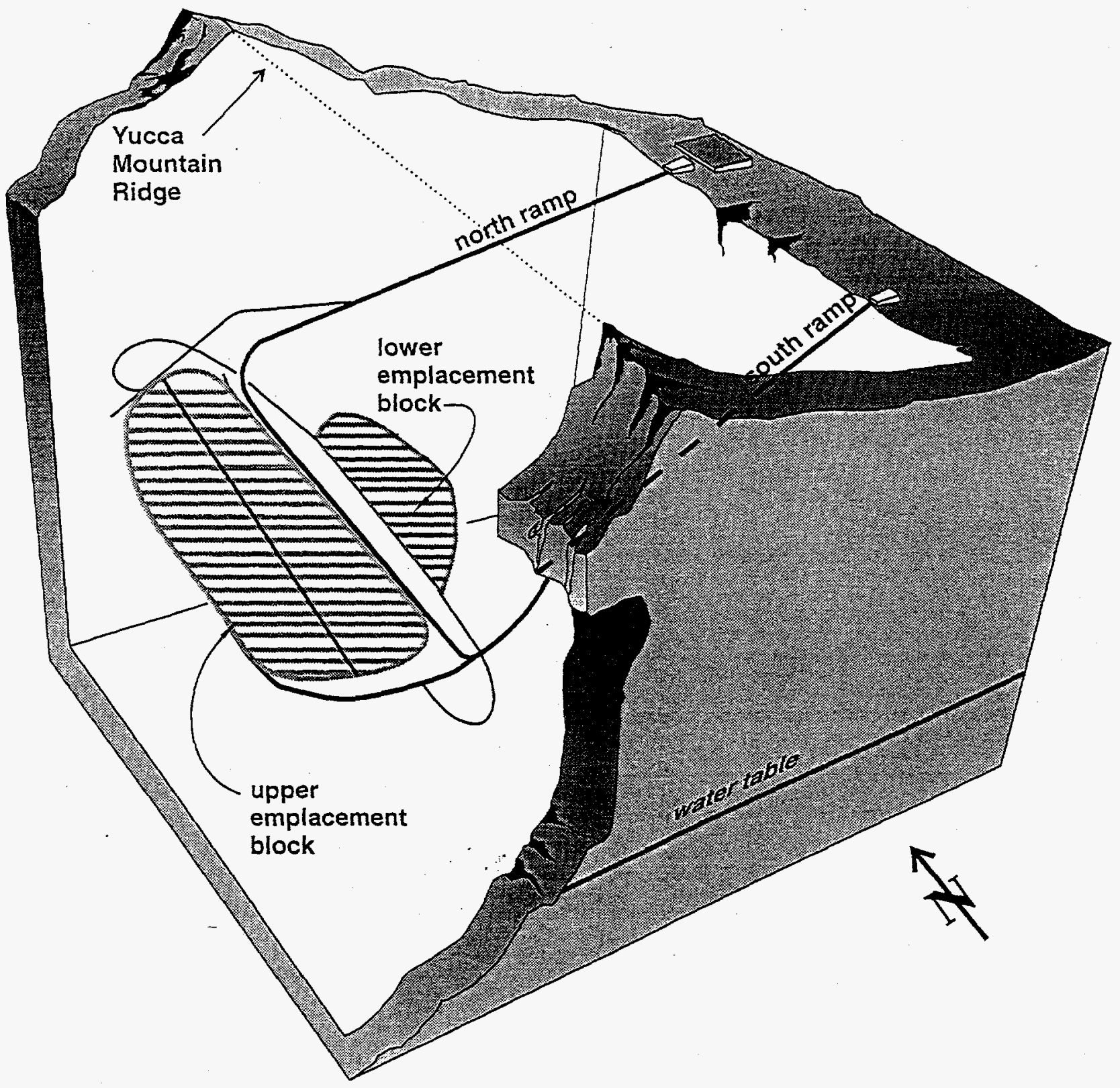

Figure 4. The subsurface of the repository will consist of about 250 kilometers (150 miles) of drifts, most of which will be used for emplacing the waste packages. The emplacement drifts will be divided into two areas. The upper block will be large and will lie to the west and slightly above the lower block. 


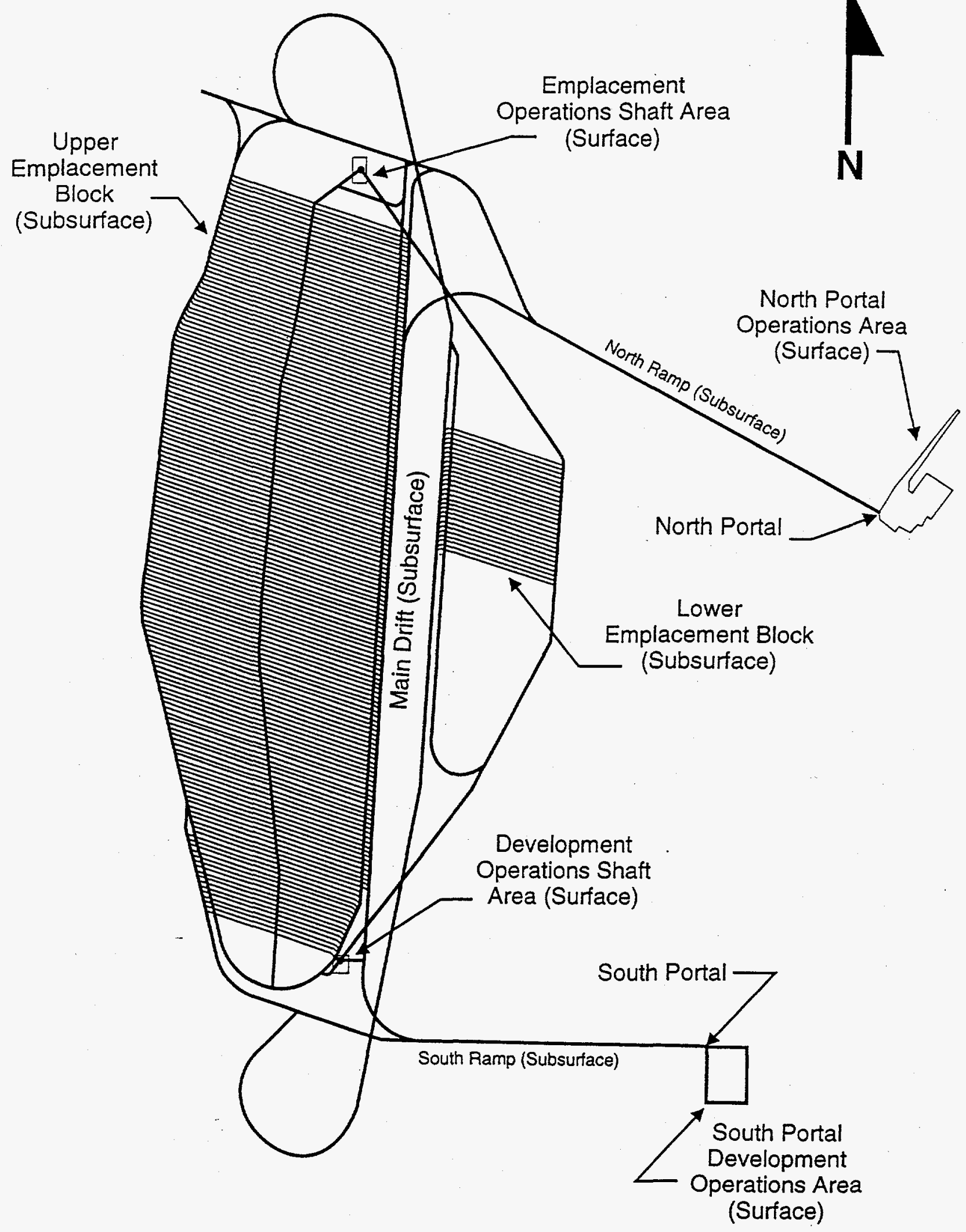

Figure 5. Overall repository site map. 
emitted by the wastes are at their peak. This occurs early in the postclosure time frame, encompassing the period of approximately 300 to 1000 years following closure. The limited amount of water flowing through the unsaturated zone is expected to enhance the ability of the container to limit the release of radionuclides. Additionally, container materials will be chosen to be compatible with the geochemical properties of the water to prolong container life should water contact it. The waste form itself is also expected to be a barrier to the release of radionuclides. The low probability of early container failure and the small amount of water available are expected to limit the dissolution and leaching of radionuclides from the solid waste materials for at least several thousand years [10].

The components of the waste packages, in this relatively dry environment, are intended to confine the waste for thousands of years. The current container designs [11] are deliberately robust; the dual wall design uses a corrosion allowance material outer layer and a corrosion resistant material inner layer to form the walls of the waste packages. The heat from the waste packages is expected to keep the rock, immediately around the emplacement drift, relatively dry for hundreds of years, which should reduce the corrosion rate of the waste packages. The air gap between the container and the host rock is also expected to contribute to limiting the release of radionuclides. Because percolation rates are expected to be low, and because most water is expected to be tightly confined in the rock matrix, little water should cross this air gap. Limited water movement in fractures is possible; however, the amount of water that could potentially contact the containers is expected to be a small fraction of that contained in the rock. As the waste packages and emplacement drifts eventually cool, water could begin to seep back toward the waste packages, especially along fractures.

After the waste packages eventually corrode and deteriorate, and the engineered barrier function is degraded, the natural barriers will provide the primary means of isolation. The various rock layers at Yucca Mountain, due to low water content and movement, are expected to retard the movement of released radioactive material to the accessible environment. Finally, any radioactive material that eventually reached the water table beneath the repository would be diluted, further reducing the potential amounts that could reach the environment.

The current repository conceptual design assumes a relatively high emplacement density of 83 metric tons of initial heavy metal (MTU) per acre (approximately $200 \mathrm{MPU}$ per hectare). The resulting emplacement scheme divides the subsurface facilities into two sets of waste emplacement drifts called blocks [11]. In this concept, the emplacement drifts would be spaced at 22.5 meters and emplacement drifts would range from about 250 meters to about 600 meters in length. The upper block would cover about 324 hectares, and could accommodate about 11,000 waste packages. The lower block would cover about 69 hectares, and could accommodate up to 2,400 additional waste packages. A total of about 12,000 waste packages are expected to be emplaced [11, 12]. Approximately 90 percent of the radioactive waste will be spent fuel in waste packages, each containing up to 9 metric tons of spent fuel. However, it is currently expected that more than one-fourth of the total number of waste packages will be high-level waste, with each package containing approximately 2 metric tons of high-level wastes. 
The physical arrangement in which waste packages would be placed underground will have an impact on the environmental conditions in the emplacement drifts. After emplacement, heat will raise the temperature of the emplacement drift rock walls. The spacing between the emplacement drifts and the spacing between waste packages within the emplacement drifts will determine how hot the emplacement drift environment and surrounding rock will become. Conceptual designs have been developed for fuel assemblies that have been shipped to the repository in containers (canistered and defense high-level waste disposal containers) that can be placed into an overpack for subsequent emplacement for disposal in the repository. Conceptual designs also have been developed for fuel assemblies that arrive in a shipping container (uncanistered) and must be repackaged for subsequent emplacement for disposal in the repository (Figure 6).

The waste packages would be mounted on rail cars that would be placed on rails within the emplacement drift. Once waste packages are placed in an emplacement drift, no human entry into that emplacement drift would be allowed under normal conditions. Two options, illustrated in Figure 7, are being studied for emplacement of waste packages within the emplacement drifts. One option, center in-drift, involves a single set of rails running down the center of the drift on which the waste package rail car unit would be placed. The diameter of this emplacement drift would be 5 meters. The other option, off center in-drift, would contain two parallel sets of rails. The rail car would be placed on one set of rails to the side of the drift, and the set on the other side of the drift would provide remote access along the drift for inspecting, monitoring and maintaining the drift, emplaced materials, and equipment. The diameter of this emplacement drift would be 5.5 meters.

Each combination of drift and package spacing, and waste package heat output, will result in a different overall thermal load. Corresponding temperatures will cause various changes in the repository rock and its water content, which can affect waste package performance. Potential changes in rock strength, water content and mineral composition depend primarily on the thermal loading. These changes are being investigated by both field and laboratory testing and by the use of computer modeling techniques. A repository design goal to not exceed wall rock temperatures of $200^{\circ} \mathrm{C}$ was established [11]. The current conceptual repository design uses a relatively high thermal loading that results in maximum emplacement drift wall temperatures of approximately $155^{\circ} \mathrm{C}$ at about 40 to 60 years after emplacement, if no ventilation is supplied to the drift after emplacement is completed [12].

As would be expected, this strategy is sensitive to disruptive processes and events, especially those that could modify the dry character of the site, which is central to the compliance arguments. Of particular importance to the strategy are climate changes and processes or events that could enhance infiltration. The effects of repository heating on the conditions of the rock mass are also of concern. A high thermal load may drive moisture away from the canisters for significant periods of time. Conversely, the temperature changes could lead to potentially irreversible changes in the hydrologic and geochemical properties of the zeolites in the rock mass. 


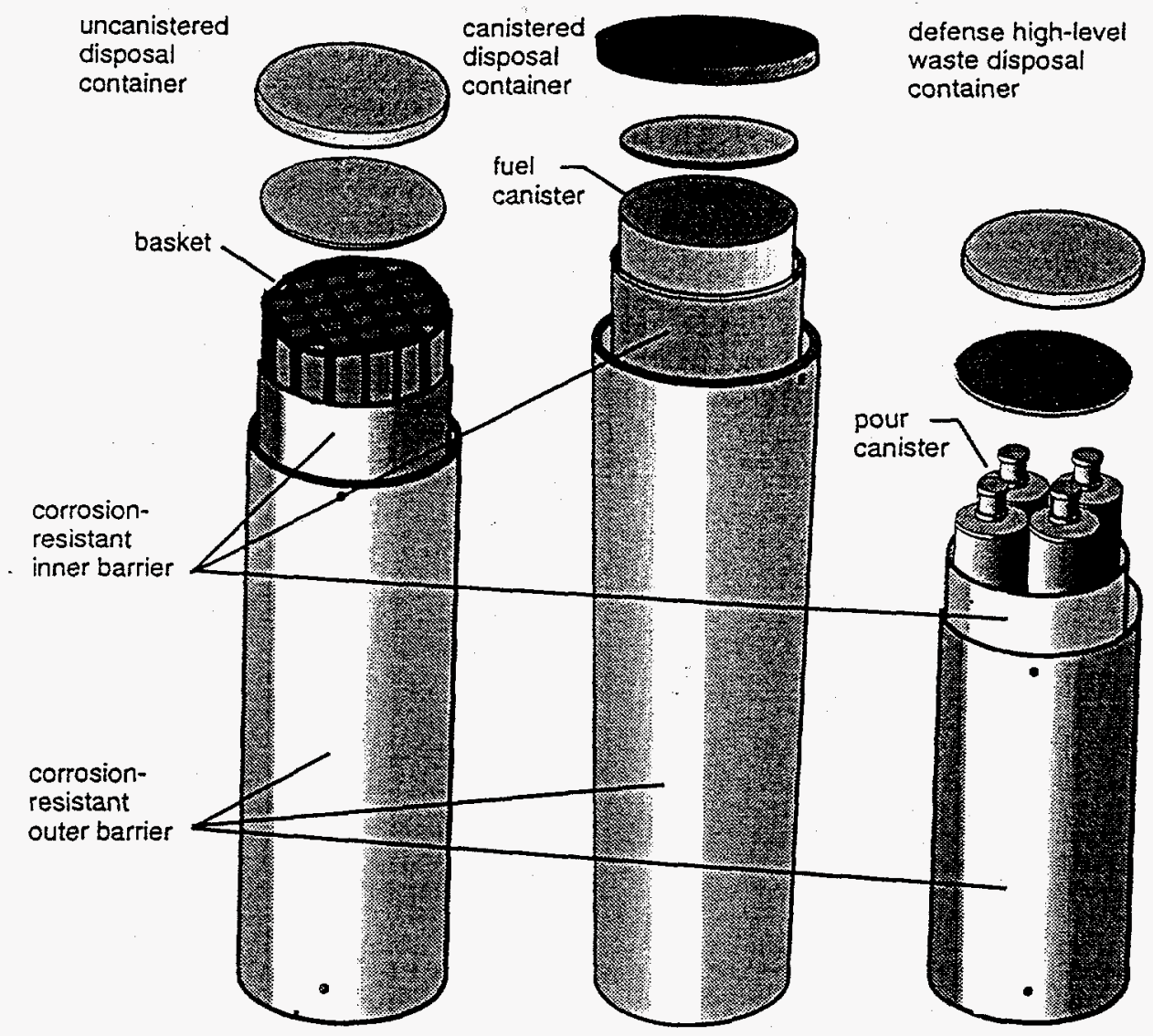

Conceptual design characteristics for disposal containers.

\begin{tabular}{|c|c|c|c|c|c|}
\hline & \multicolumn{2}{|c|}{ Uncanistered } & \multicolumn{2}{|c|}{ Canistered } & \multirow[t]{2}{*}{ DHLW } \\
\hline & large & small & large & small & \\
\hline \multicolumn{6}{|c|}{ Capacity (number of fuel assemblies or pour canisters) } \\
\hline PWR & 21 & 12 & 21 & 12 & -- \\
\hline BWR & 44 & 24 & 40 & 24 & $-\cdots$ \\
\hline Canisters & $-\cdots$ & --- & $\cdots$ & $\cdots$ & 4 \\
\hline \multicolumn{6}{|c|}{ Dimensions in millimeters } \\
\hline Diameter & $\begin{array}{l}1629 \\
(64 ")\end{array}$ & $\begin{array}{r}1298 / 1265^{*} \\
\left(51^{\prime \prime} / 50^{\prime \prime}\right)\end{array}$ & $\begin{array}{l}1802 \\
\left(71^{\prime \prime}\right)\end{array}$ & $\begin{array}{l}1531 \\
\left(60^{\prime \prime}\right)\end{array}$ & $\begin{array}{l}1709 \\
\left(67^{\prime \prime}\right)\end{array}$ \\
\hline Length & $\begin{array}{r}5335 \\
\left(210^{\prime \prime}\right)\end{array}$ & $\begin{array}{r}5335 \\
\left(210^{\prime \prime}\right)\end{array}$ & $\begin{array}{r}5682 \\
\left(224^{\prime \prime}\right)\end{array}$ & $\begin{array}{r}5647 \\
\left(222^{\prime \prime}\right)\end{array}$ & $\begin{array}{r}3680 \\
\left(145^{\prime \prime}\right)\end{array}$ \\
\hline \multicolumn{6}{|c|}{ Weight in kilograms (approximate) } \\
\hline Empty & $\begin{array}{r}31,000 \\
\text { (34 tons) } \\
\end{array}$ & $\begin{array}{r}22,000 \\
(24 \text { tons }) \\
\end{array}$ & $\begin{array}{r}31,000 \\
\text { (34 tons) }\end{array}$ & $\begin{array}{r}25,000 \\
\text { (28 tons) }\end{array}$ & $\begin{array}{r}13,000 \\
\text { (14 tons) }\end{array}$ \\
\hline Loaded & $\begin{array}{r}47,000 \\
\text { (52 tons) }\end{array}$ & $\begin{array}{r}31,000 \\
\text { (34 tons) }\end{array}$ & $\begin{array}{r}65,000 \\
\text { (72 tons) }\end{array}$ & $\begin{array}{r}47,000 \\
\text { (52 tons) }\end{array}$ & $\begin{array}{r}22,000 \\
\text { (24 tons) }\end{array}$ \\
\hline
\end{tabular}

PWR - Pressurized Water Reactor BWR - Boiling Water Reactor

- larger diameter for PWR, smaller diameter for BWR

Figure 6. Conceptual designs address disposal containers for fuel assemblies not in canisters, fuel assemblies in canisters, and pour canisters. 


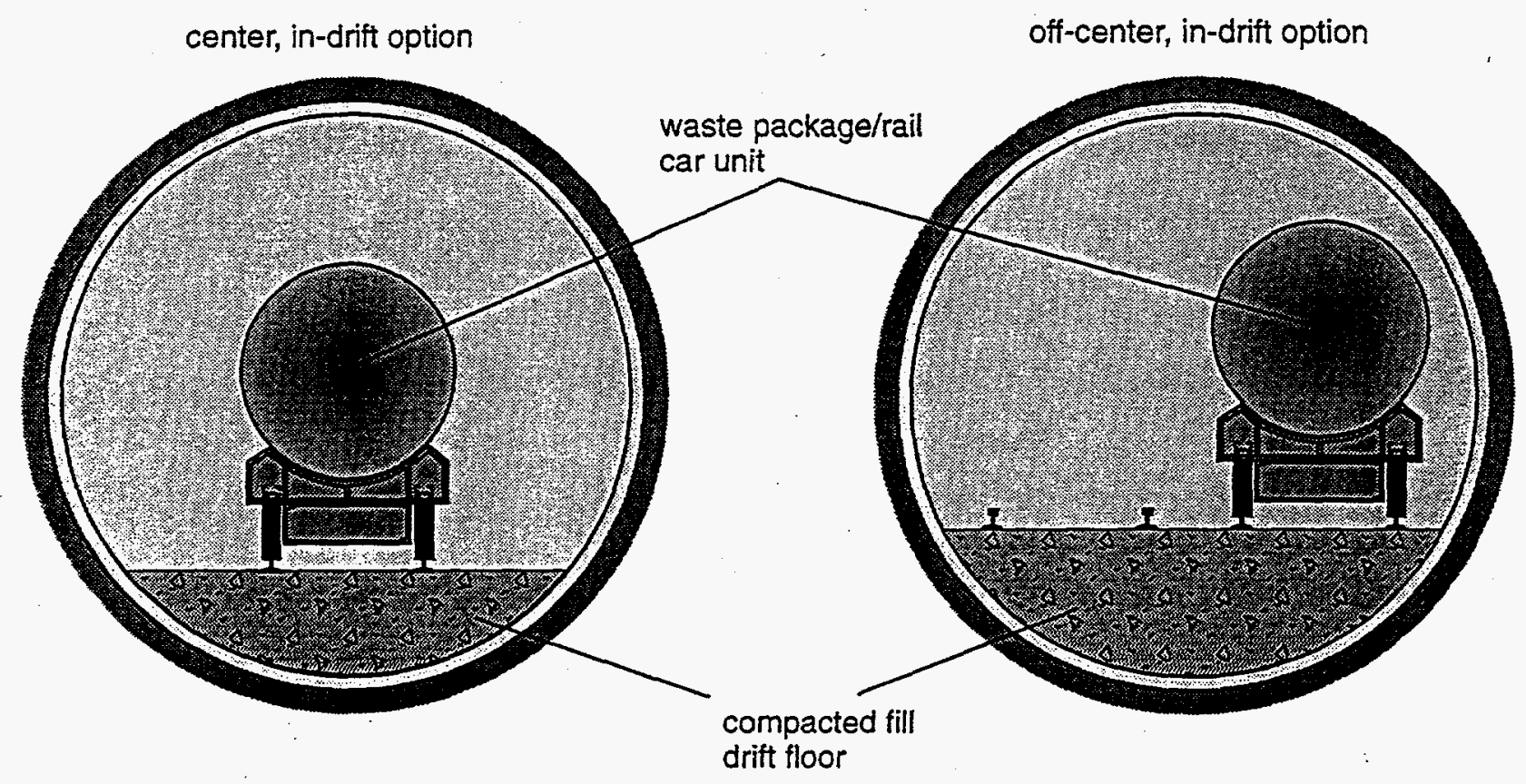

Figure 7. The conceptual design for the emplacement drifts includes two options. One will have a single set of rails for placing the waste package in the center of the drift. The other will have two sets of rails for placing the waste package to one side of the drift. 
Another issue of engineered barrier performance is related to the presence in the waste of gaseous radionuclides such as ${ }^{14} \mathrm{CO}_{2}$. The natural barriers at Yucca Mountain are not likely to be effective in containing gases that could be released through eventual failure of waste containers. Early waste package failure could lead to the release of quantities of ${ }^{14} \mathrm{CO}_{2}$ that could possibly violate the remanded standard for total curies released, even though there would be no significant associated health effects. Although the standard has been remanded, it is still used as a standard for comparison by the program until a new one is in place. The waste packages likely could be designed to contain the gases, but the lack of true health and safety protection makes it difficult to justify the costs.

\section{Results of Site Characterization Completed to Date}

The test program described in the Site Characterization Plan [2] included both surface based and underground test programs, the latter in a facility developed at the base of an exploratory shaft. Review comments on that plan from the Nuclear Regulatory Commission [13] and the United States Nuclear Waste Technical Review Board [14] were addressed [15] and, in so doing, the configuration was changed from shaft access to ramp access. The resulting facility design incorporated requirements to support a test program to address data needed to assess the role of both the engineered barriers and the natural barriers. Heater tests, ranging in scale up to room size, will be conducted over the next several years to investigate coupled thermal-mechanicalhydrological-geochemical processes, moisture movement, mechanical effects, and near field effects. Other underground tests underway or planned include construction tests, which examine excavation methods, measurements of the response of ground support systems, possible emplacement equipment tests, seal component tests, seismic tomography, and rock strength tests. Hydrology and transport will be studied through suites of tests such as large scale permeability tests, radial borehole permeability (gas and water) tests, hydrochemistry tests, mapping, diffusion tests, radionuclide transport tests (using non-radioactive tracers) and percolation tests, potentially above, at and below the repository horizon. The field experiments are complemented by laboratory tests, including, thermal, mechanical, hydrological and rock water interaction.

Observations of the natural system and site data collected since 1978 suggest that the natural system is robust, and that numerical models and calculations will be able to bound many of the uncertainties for radiological safety evaluations, leading to enhanced confidence in the performance of the site. No major unexpected conditions have been encountered; tunneling and testing are confirming the hypotheses on site conditions described in the 1986 Environmental Assessment and the 1988 Site Characterization Plan. Recent performance assessments [10] have led to increased confidence that a Yucca Mountain repository would contain and isolate radioactive waste and would meet a reasonable EPA standard. Disruptive events, such as volcanism or seismicity, are considered unlikely to adversely impact performance. The project recently completed an independent external expert elicitation on probabilistic volcanic hazards [16] that affirmed the project position on low (order of $10^{-8}$ per year) probability of a volcanic event penetrating the repository. An improved site and engineering data base supports performance assessment calculations that provide more realistic bounding conditions. 
Site hydrologic models [17] indicate groundwater flux is likely to be limited and very low at the repository horizon, possibly with local exceptions. The results of modeling and field investigations support a conclusion that infiltration could be diverted laterally away from the repository horizon, owing to the distinctly different hydrologic properties at the contact between course-grained and permeable non-welded tuff, and underlying and overlying fine-grained and relatively impermeable welded tuff layers. (Figure 3 ). These hydrologic conditions have the potential to buffer the effects of increased infiltration that could occur as a result of climatic changes. Exploratory studies facility tunneling progress has greatly increased the opportunity for underground observations and confirms constructability and geologic characteristics with no observable water seepage. Also, extensive underground drifting, which provides a greater opportunity for observation and sampling, has supplanted the originally proposed drilling program.

\section{Planned Future Work}

Program scientists and management today believe that a reduction in the scope of the characterization program from that originally proposed is justifiable and desirable. This reduced scope is supported both through increased understanding gained through progress in the characterization program and through realignment of licensing expectations with the information that can reasonably be obtained at different phases of the program [18]. The current understanding of the importance of the individual elements of the disposal system is better and more quantitative than at the time the Site Characterization Plan was written. Some of the uncertainties identified in the Site Characterization Plan are now known to be not as important as others. Performance assessments and modeling have identified the most important uncertainties and methods to bound resolution of other uncertainties without executing every activity of the extensive characterization program originally described in the Site Characterization Plan. What has been learned leaves fewer, but still technically important, questions to be answered about significant features and processes of the natural geologic, hydrologic, and engineered components that would be part of a potential Yucca Mountain repository.

In addition to new site characterization information and performance based analyses capable of evaluating total system performance, other developments such as updated repository and waste package conceptual designs, and considerations related to the change from a release standard to a dose or risk-based standard, with an as-yet unspecified regulatory time frame, have contributed to the need to refine the strategy for evaluating waste containment and isolation.

The updated strategy currently being developed maintains a number of fundamentals of the original strategy. The updated strategy continues to recognize the important role of the relatively dry conditions at Yucca Mountain, which contributed to the site originally being selected for characterization studies. The updated strategy also continues to recognize the geochemical setting provided by Yucca Mountain as important to determining the rate at which radionuclides may be released into the environment in the future, when containment by the waste packages is eventually lost. 
The current program is structured around a series of major products leading to an eventual license application. One of the most visible major products in the near term is a Viability Assessment to be completed in 1998. The Viability Assessment has four components:

(1) design of critical parts of the repository, waste packages, and engineered barrier system;

(2) a performance assessment that incorporates current knowledge of natural features, processes, and responses at Yucca Mountain, and that evaluates the long term performance of the total natural and engineered system;

(3) a Total System Life Cycle Cost estimate for the construction, operation, and closure of the repository; and

(4) a Licensing Plan to lay out tests, design activities, or other actions needed to complete an initial license application for submittal to the United States Nuclear Regulatory Commission.

The purpose of the Viability Assessment is to provide policy makers with an integrated view of a repository system, its estimated performance capabilities, and the associated cost and schedule. If policy makers accept and endorse that assessment, it is anticipated that resources will be committed to ensure continued progress toward the license application.

Current project planning also reflects the need to complete field studies and analyses to reduce uncertainty and enhance understanding of system performance to support the assessment of system safety needed for the license application. The larger technical questions identified in recent total system performance assessments [10] as key to evaluating repository and waste package performance are related to the following attributes of the system:

(1) Rate of water seepage into the repository

(2) Integrity of waste packages (containment)

(3) Rate of release of radionuclides from waste in the breached waste packages

(4) Radionuclide transport through engineered barriers and natural barriers

(5) Dilution in the groundwater below the repository.

The refined waste isolation and containment strategy will also address what approach will be taken to gathering data and developing models to make better predictions of these attributes over time. As the repository generates heat and then gradually returns to ambient temperatures, it is expected that at least the first four of these attributes will be affected, changing their relative importance to system performance as a function of time. 
In the absence of a definitive compliance standard for geologic disposal, the United States Department of Energy is defining waste containment and isolation for purposes of conducting the viability assessment in such a way as to be independent of the specific compliance measures that eventually will be promulgated [19]. Waste containment has been defined as: the near-complete containment of radionuclides by waste packages for several thousands of years. Isolation has been defined with a system-level safety goal as: an acceptable dose to a member of the public living near the site. Quantitative dose modeling results will be used to evaluate compliance with applicable standards; more attention will be paid to evaluating potential doses for the first ten thousand years. However, calculations will be carried out over longer times in order to provide qualitative insight into peak dose potential, and to support system enhancement studies.

The United States Department of Energy recognizes there are issues which cannot be completely resolved in the 1998 Viability Assessment. Scientific and engineering studies will continue to be conducted to guide confirmation of or revision to the basis for modeling performance of the repository system. There is an expectation that additional data and analyses will be required to support a license application. It also recognizes that, if a license is granted, confirmatory technical work will continue beyond the time of license application into the construction and operational phases of the repository.

\section{Conclusions}

Following amendment in 1987 of the legislation authorizing characterization of sites for a repository, the United States' high-level waste program focused on Yucca Mountain in the southwestern United States as the single site under consideration. The attributes of Yucca Mountain that made it technically attractive nearly twenty years ago continue to be the technical underpinnings of the strategy for long term waste containment and isolation. Significant progress has been made in the characterization of Yucca Mountain as a potential site for a mined geologic repository. Conditions encountered in the exploratory studies facility tunnel at repository depth are consistent with expectations of such a facility constructed in the unsaturated zone. Total system performance assessments of the long term behavior of a repository at Yucca Mountain continue to mature, and have provided significant guidance in helping define priorities in the test programs and design solutions for the engineered barriers.

The technical strengths of the Yucca Mountain site depend on limited water available to contact the wastes and a corresponding high potential for isolation of the wastes. Today, the United States regulatory approach to long term compliance is uncertain. While the United States Nuclear Regulatory Commission regulations are in place, the United States Environmental Protection Agency standards for disposal safety are remanded. Actions underway to develop a new standard for disposal safety are reopening issues fundamental to the structure of the regulatory approach.

The United States high-level waste program regulations were, in the past, based on a relatively long time frame of regulatory interest, 10,000 years, and assessed compliance against limits on total system releases at an accessible environment, located five kilometers from the repository. 
The National Academy of Sciences [9] recommendation that the United States adopt a dose based standard for postclosure compliance for a repository has raised issues relative to the regulatory time frame, dose and risk, the definition of the reference biosphere, human intrusion and the quantitative treatment of natural processes and events. Deliberation of these issues is expected to be intense and time consuming, and fundamental re-evaluation of the United States approach to long term compliance should not be unexpected.

Technically, the Yucca Mountain site remains attractive because of its great potential to isolate wastes. However, there are significant concerns about the ability to bring to closure a regulatory proceeding that could have to deal with what are unprecedented time frames in the context of regulation. The potential for a geologic disposal standard that could introduce a need to rely on dilution in a closed hydrologic basin to meet a dose based standard takes the United States highlevel waste program full circle back to the promulgation of the United States Environmental Protection Agency standards for geologic disposal. In those proceedings, a dose based standard was considered to be an inappropriate policy that could increase overall population exposures by encouraging disposal methods that would enhance dilution of any radionuclides released [5].

The extent to which the Yucca Mountain site eventually can be shown to be in compliance with a regulation that is evolving amid questions about the very nature of the regulatory structure that has been the basis for selection of the site, and assessment of its performance for nearly twenty years, is a significant concern. This reassessment is occurring even as the geologic and engineering disciplines are beginning to evolve data sets that are unprecedented in depth, breadth, and specificity for evaluating the Yucca Mountain site for its waste isolation potential.

\section{References}

1 United States Congress. Nuclear Waste Policy Amendments Act of 1987. Public Law 100203, 100th Congress, December 22, 1987.

2. Unites States Department of Energy. Site Characterization Plan. Yucca Mountain Site, Nevada Research and Development Area, Nevada. Office of Civilian Radioactive Waste Management, Report DOE/RW-0199, December 1988.

3. United States Congress. Waste Isolation Pilot Plant Land Withdrawal Act. Public Law 102-579, 102d Congress, October 30, 1992.

4. United States Congress. Nuclear Waste Policy Act of 1982. Public Law 97-425, 97th Congress, January 7, 1983.

5. United States Environmental Protection Agency. Environmental Standards for the Management and Disposal of Spent Nuclear Fuel, High-level and Transuranic Radioactive Wastes. (40 CFR Part 191). Federal Register, vol. 50, no. 182, Sept. 19, 1985. 
6. United States Nuclear Regulatory Commission. Disposal of High-level Radioactive Wastes in Geologic Repositories. Code of Federal Regulations, Title 10, Part 60.

7. United States Congress. Energy Policy Act of 1992. Public Law 102-486, October 24, 1992.

8. National Research Council, Board on Radioactive Waste Management, Waste Isolation Systems Panel, United States National Academy of Sciences. A Study of the Isolation System for Geologic Disposal of Radioactive Wastes. National Academy Press, Washington, D.C. 1983.

9. National Research Council. Technical Bases for Yucca Mountain Standards. Committee on Technical Bases for Yucca Mountain Standards, Board on Radioactive Waste Management, United States National Academy of Sciences. National Academy Press, Washington, D.C., 1995.

10. Civilian Radioactive Waste Management System Management and Operating Contractor. Total System Performance Assessment - 1995: An Evaluation of the Potential Yucca Mountain Repository. B00000000-01717-2200-00136, Rev. 01, November 1995.

11. Civilian Radioactive Waste Management System Management and Operating Contractor. Mined Geologic Disposal System Advanced Conceptual Design Report. B000000000171705705-0002,. Rev. 00, March 1996.

12. McKenzie, Daniel.G., III, Kalyan K Bhattacharyya, and Alden Segrest. Conceptual Subsurface Facility Design for a High Level Nuclear Waste Repository at. Yucca Mountain. 37th Annual Meeting of the Institute of Nuclear Materials Management. July, 1996.

13. United States Nuclear Regulatory Commission. NRC Staff Site Characterization Analysis of the Department of Energy's Site Characterization Plan, Yucca Mountain Site, Nevada. NUREG-1347. August 1989.

14. United States Nuclear Waste Technical Review Board. First Report to the United States. Congress and the United States Secretary of Energy, March 1990.

15. Dennis, A. W. (editor). Exploratory Studies Facility Alternatives Study: Final Report. Sandia National Laboratories, SAND91-0025. September, 1991.

16. Geomatrix Consultants, Probabilistic Volcanic Hazard Analysis for Yucca Mountain, Nevada, Draft Report, Volumes I, II, March, 1996.

17. Wittwer, C., Chen, G., Bodvarsson, G.S., Chornack, M., Flint A., Flint L., Kwickless, E., and Spengler, R.. Preliminary Development of the LBLUSGS Three Dimensional Site Scale Model of Yucca Mountain, Nevada. Lawrence Berkeley National Laboratory Report. LBL37356/UC-814. June 1995. 
18. United States Department of Energy. Civilian Radioactive Waste Management Program Plan. DOE/RW-0458. December, 1994. $7=$

19. United States Department of Energy. Civilian Radioactive Waste Management Program Plan. Draft Revision 1. DOE/RW-0458. May, 1996. 